UDC 331.107.5:164(045)

DOI: https://doi.org/10.32782/2520-2200/2019-6-69

\author{
Pekar Yuliia \\ National Aviation University \\ Kyrylenko Oksana \\ National Aviation University \\ Teplinskii Hennadii \\ National Aviation University
}

Пекар Ю.С.

студентка

Національного авіаційного університету

Кириленко О.М.

доктор економічних наук, професор,

Національний авіаційний університет

Теплінський Г.В.

кандидат економічних наук, доцент,

Національний авіаційний університет

\title{
MECHANISMS OF THE PUBLIC-PRIVATE PARTNERSHIP IN IMPLEMENTATION OF LOGISTIC INFRASTRUCTURE PROJECTS
}

\section{МЕХАНІЗМИ ПУБЛІЧНО-ПРИВАТНОГО ПАРТНЕРСТВА В РЕАЛІЗАЦІї ПРОЕКТІВ ЛОГІСТИЧНОЇ ІНФРАСТРУКТУРИ}

The aim of the article is to analyze the development of infrastructure projects and identify effective mechanisms for involving public-private partnerships in this field. The article considers the peculiarities of logistics industry Ukraine, the cost of infrastructure as a percent of GDP. Public-private partnership is examined, organizational and economic entity of partnership is revealed. Despite the advantages and their effectiveness, a number of domestic public-private partnership in infrastructure projects are scarce. We suppose the problem is caused by imperfection of legislation that regulates the formation of logistic infrastructure and public-private partnership, lack of investors and financing. Development of financial initiative of the private business which has a possibility and is ready to invest in the logistics sector, is one of a few tools for implementation of infrastructure projects with government support.

Key words: logistic, infrastructure, public-private partnership, public-private partnership project.

Метою статті $є$ аналіз розвитку інфраструктурних проектів та визначення ефективних механізмів залучення державно-приватних партнерств у галузі логістичних інфраструктурних проектів. У статті розглядаються питання, що стосуються використання державно-приватного партнерства в логістичній інфрраструктурі. У статті розглядаються особливості логістичної галузі України, місце в рейтингу показника ефрективності логістики та вартість інфрраструктури у відсотках до ВВП. Поширеним явищем в економіці різних країн є взаємодія між бізнесом та державою, яку називають державно-приватним партнерством. Публічно-приватне партнерство розглянуто як механізм створення логістичних інфрраструктурних проектів, розкрито поняття організаційно-господарського суб'єкта державно-приватного партнерства, наведені його форми і моделі, ризики між сторонами партнерства. Розглянуто критерії реалізації публічно-приватних партнерств: зменшення бюджетних витрат, поліпшення якості обслуговування, тривалість партнерських відносин, необхідний рівень інституційного середовища, мінімізація реалізації корупційних проектів. Незважаючи на переваги та їх ефективність, кількість національних державно-приватних партнерств в інфрраструктурних проектах $€$ дефіцитною. Ми припускаємо, що проблема спричинена недосконалістю законодавства, яке регулює формування та діяльність логістичної інфрраструктури, а також державно-приватне партнерство, відсутність інвесторів та відсутність фінансування. Поточні фінансові потреби не забезпечують необхідний рівень розвитку логістичної інфраструктури. Ми вважаємо доцільним подальший розвиток фінансової ініціативи приватного бізнесу, який має можливість і готовий інвестувати в логістичний сектор із зворотним зв'язком у вигляді державних гарантій у рамках державно-приватного партнерства, який на сьогодні є одним із небагатьох інструментів реалізації інфрраструктурних проектів за підтримки уряду.

Ключові слова: логістика, інфрраструктура, державно-приватне партнерство, проекти державно-приватного партнерства. 
Целью статьи является анализ развития инфраструктурных проектов и выявление эффрективных механизмов привлечения государственно-частных партнерств в этой области. В статье рассматриваются особенности логистической отрасли Украины, стоимость инфраструктуры в процентах от ВВП. Рассмотрено государственно-частное партнерство, выявлена организационноэкономическая сущность партнерства. Несмотря на преимущества и их эффективность, ряд отечественных государственно-частных партнерств в инфраструктурных проектах скуден. Мы полагаем, что проблема вызвана несовершенством законодательства, регулирующего формирование логистической инфраструктуры и государственно-частного партнерства, нехваткой инвесторов и финансирования. Развитие фринансовой инициативы частного бизнеса, которая имеет возможность и готова инвестировать в логистический сектор, является одним из немногих инструментов для реализации инфраструктурных проектов при государственной поддержке.

Ключевые слова: логистика, инфраструктура, государственно-частное партнерство, проект государственно-частного партнерства.

Problem statement. Ongoing social and economic challenges prompt the state to find optimal ways to exercise its own functions. Policies related to increasing state influence on economic processes or, conversely, minimizing control over the market environment do not provide clear answers to the significant benefits of any particular approach. Separate application of market mechanisms and state regulation does not solve all the existing problems of society related to the implementation of large-scale, socially important infrastructure projects. Innovative management theories offer approaches based on the combination of positive public and private sector opportunities through partnerships. Most of the countries in the world use these mechanisms, known as "public-private partnerships" (hereinafter referred to as PPP). The experience of PPP projects proves that the creation of infrastructure in this way is quite successful and promising, taking into account both public and private goals. Investing in infrastructure development allows social and economic growth, achievement of sustainable development goals and reduction of climate risks.

Unfortunately, the transport and logistics sector in Ukraine has for decades been in a state of technological backlog, insufficient level of project financing, low efficiency of operation, with a high percentage of depreciation of fixed assets. The proposed draft of National Transport Strategy for 2030 defines the development of transport as a basic branch of the economy, which forms effective mechanisms of state management of the transport and logistics system, the integration of Ukraine into the European infrastructure network, the growth of state security factors, the improvement of quality of services. The purpose of the above strategy is to create an integrated transport infrastructure of Ukraine in the world transport network, to focus on the needs of transport services consumers and to create favorable conditions for business, which will ensure the competitiveness and efficiency of the national economy [1].
The implementation of large-scale plans requires considerable financial resources (only for the creation of a modern road network the need is UAH 322.5 billion, of which nearly UAH 176 billion is state budget funds [2]), which the state must attract from various sources, including the use of public-private partnership mechanisms.

Analysis of recent research and publications. Scientists such as M. Kumar, H. Rudolph, S. Castro, S. Carpintero, and others have devoted their research to the mechanisms of public-private partnership. Problems in the development of logistics infrastructure were considered by M. Grigorak, G. Zhovtyak, S. Fabbro, V. Salet and others. However, some issues regarding the use of public-private partnership mechanisms in the implementation of logistics infrastructure projects remain insufficiently covered.

The purpose of the article is to analyze the development of infrastructure projects and identify effective mechanisms for involving public-private partnerships in the field of logistics infrastructure projects.

Presenting main material. For long-term national and regional development, logistical infrastructure is crucial and needs careful planning and implementation. During the implementation of projects for the development and operation of logistics infrastructure, it is necessary to focus on the main components that are involved in most projects for the construction or operation of logistics facilities. Logistics infrastructure includes roads, seaports, railways, airports and similar facilities [3, p. 49]. The components of logistics infrastructure are also: buildings, production areas; warehouses, loading and unloading terminals and logistics centers; means of transportation or communication; trading networks; manufacturing enterprises; operators [4]. In accordance with the objectives of the article, we will focus on the elements of logistics infrastructure related to transport facilities, which contains: highway, railway, water, air systems (highways, stations, terminals, railways, ports, 
canals, airports, etc.) with all their components and links [5].

The International Monetary Fund estimates [6] that for advanced economies, investing an additional $1 \%$ of Gross Domestic Product (hereafter GDP) on infrastructure will, on average, increase GDP by $1.5 \%$ over four years. In emerging markets, institutional and budgetary reforms can be even better.

There are some positive developments in terms of investment attractiveness in Ukraine. According to the results of a survey of member companies of the European Business Association, the Index of Investment Attractiveness of Ukraine in the second half of 2017 remains in the neutral plane with an indicator of 3.03 points on a 5-point scale (Likert scale). In the first half of 2017, an index of 3.15 points left the negative plane for the first time since 2011 [7]. Given the scale of the highways in Ukraine and future needs, the above indicators, which reflect investment attractiveness, need improvement. According to the State Statistics Service [8], Ukraine has 20.9 thousand $\mathrm{km}$ of public tracks, $1569 \mathrm{~km}$ of public navigable river routes, 159.5 thousand $\mathrm{km}$ of public roads with a hard surface.

Given the priority of Ukraine's European integration, there is a need to attract significant investment resources in the development of logistics infrastructure, development of transport and logistics. An important step in infrastructure planning is the expansion of the TEN-T (Trans-European Transport Network) map and the TRASECA Europe-Caucasus-Asia transport corridor project.

Logistics indicators play a central role in economic growth and competitiveness of countries, and the logistics sector is now recognized as one of the main elements of economic development. The state continues to pursue a consistent policy to stimulate uninterrupted and sustainable supply chain operations as a driving force for growth. Effective logistics connects businesses with domestic and international markets through reliable networks. Countries characterized by low logistical productivity face high costs not only because of transport costs but also because of unreliable supply chains, which is a major barrier to integration and competition.

According to the Logistics Efficiency Index (2.74), in 2016, Ukraine ranks 80th out of 160 countries. This indicator is a result of the assessment of countries on a five-point system on several characteristics of the logistics sector: customs, international shipments, logistics quality and competence, tracking and tracing, infrastructure, timeliness [9].

Table 1 provides a comparison of the country's logistics infrastructure assessment against the criteria of the Logistics Performance Index. In Ukraine, there are low indicators in assessing the possibilities of organizing international transportations, the quality of logistics services and the efficiency of customs handling of cargo.

The problems faced by the transport infrastructure sector are related to market specificities, when transport demand is too low to justify private investment in the sector, and the difficulties of the state, when high budgetary costs create little social and territorial benefits. In general, infrastructure contributes to social development economically, creates systems that can move goods, people and information over long distances quickly and reliably, and improve the well-being of the population.

Transformation processes in infrastructure are linked to technical problems, institutional issues, financial investments and regional development strategies, which require the joint involvement of technical experts, policy makers and managers. Infrastructure plays a crucial role in the construction of the territory in the physical and socio-economic directions [10]. While preparing the region for the creation of transport infrastructure projects, the projects are integrated into a multi-purpose regional development strategy, bringing changes to the strategic mission, taking into account the environmental impact, economic development, etc. [11].

Understanding the peculiarities of the region, needs and opportunities, industrial, cultural, tourist, recreational, transport, scientific and educational potential makes it possible to formulate

Table 1

Assessment of logistics infrastructure of individual countries by the criteria of the logistics performance index (LPI) [9]

\begin{tabular}{|l|c|c|c|c|c|}
\hline \multicolumn{1}{|c|}{ Criteria for LPI } & Ukraine & Egypt & Vietnam & Indonesia & Belarus \\
\hline Efficiency of customs handling of cargo & 2.3 & 2.75 & 2.75 & 2.69 & 2.06 \\
\hline Quality of infrastructure & 2.49 & 3.07 & 2.7 & 2.65 & 2.1 \\
\hline International shipments & 2.59 & 3.27 & 3.12 & 2.9 & 2.62 \\
\hline Logistics quality & 2.55 & 3.2 & 2.88 & 3 & 2.32 \\
\hline Tracking and tracing & 2.96 & 3.15 & 2.84 & 3.19 & 2.16 \\
\hline Timeless & 3.51 & 3.63 & 3.5 & 3.46 & 3.04 \\
\hline
\end{tabular}


strategies for engaging public-private partnership mechanisms.

The inefficiency of the state monopoly on public service delivery and the lack of public investment prompts private capital to become involved in infrastructure projects to provide services [12]. Public-private partnerships are considered an important mechanism for developing logistics infrastructures, especially in emerging market economies [13]. PPP emerges as a combination of the public and private sectors in different dimensions, while maintaining their own characteristics, mutual competition or cooperation in the market [14, p. 65].

Today USD 9.5 trillion or about $14 \%$ of world's GDP is invested in infrastructure and real estate in the world. But despite this, countries face significant gaps in infrastructure. Investment in transport infrastructure needs to be estimated at USD 29.6 trillion by 2035 . Nearly two-thirds of global infrastructure investment by 2035 requires emerging economies [15]. Investment commitments in the transport sector in low- and middle-income countries in the first half of 2017 amounted to USD 8.7 billion, equivalent to $34 \%$ of the 2016 PPP annual commitments in the sector. Of the 31 transport projects that reached financial completion in the first half of 2017, 19 were road projects and eight were ports. Road infrastructure projects attracted the largest investment in transport in the first half of 2017, while USD 5.8 billion was allocated for 19 projects. This is almost twice the amount allocated to the roads in the first half of 2016, during which road investments decreased and railways received the largest amount of funds. The ports ranked second in terms of PPP investment, USD 2.4 billion. aimed at eight projects [16].

The transport sector is one of the priority sectors for PPP as it enables: economies of scale, receiving usage fees, quality assurance of services. The institutional and regulatory frameworks of PPP are based on comprehensive programs of carefully prepared infrastructure projects, accompanied by essential PPP conditions; enhancing project preparation with an adequate and symmetric level of stakeholder information, transparent bidding processes that give sufficient time to prepare proposals from international investors; standardization of PPP agreements to facilitate private sector involvement and reduce transaction costs; creating conditions for competition of foreign entities in PPP programs; attracting project bonds, equity and debt funds in the capital market for use as a benchmark by internal institutional investors; stimulation of long-term investments [17].

According to a study [18], the main directions of PPP strategy in infrastructure projects are iden- tified: solving the problem of limiting public sector budget expenditures, reducing the total cost of the project, saving time to implement the project, accelerating the development of the project, commitment (responsibility) of the state and private sector, quality and correct cost-benefit assessment. The widespread use of PPP mechanisms in logistics infrastructure is evidenced by the prevalence of this model of project implementation. As an example, more than 350 private sector projects have been implemented in ports in nearly 60 developing countries over the last 20 years. The largest number of PPP projects were implemented through the model of concession agreements $(48 \%)$ and investments in new infrastructure projects $(40 \%)$. Less popular models were management and leasing contracts $(7 \%)$, sales of shares in equity $(6 \%)$. The most common private partners are global terminal operators, regional operators, shippers, transport companies, equipment manufacturers, industrial conglomerates and financial institutions.

During the construction and operation of PPP models, the public sector is responsible for port planning, regulatory functions and ownership of land and basic infrastructure. The private sector is responsible for offshore and terminal operations, as well as for the construction, acquisition and ownership of facilities and equipment. The successful use of PPP is based on the optimum value for money, which implies: risk sharing; maximize the benefits of private sector efficiency, knowledge, skills, flexibility and innovation; the principle of preserving the integrity of public service delivery and the availability of public utility; the principle of transferring expert and professional knowledge from a private partner to a public partner. Priority criteria for PPP assessment remain: improvement of management function, intellectual capital, duration of partnership and control of business processes. The duration of the partnership is recognized as an important criterion because it promotes long-term relationships and the stability of the partnership for a longer period of time under the conditions specified in the main agreement [19, p. 226-228].

A common form of PPP in the logistics chain is a concession - the right to use land, infrastructure and facilities for a limited period of time in exchange for the obligation to provide services (cargo handling). The key features of the concession are that the main terminal infrastructure remains state-owned and the terminal operations are controlled by an independent enterprise partly owned by private companies. The operator has the right to use public assets for a certain period of time and to act with considerable entrepreneurial freedom. In many cases, the operator 
is also entitled or obliged to invest in the terminal [20]. The concessionary form of public-private partnership is attractive to both the private owner and the state.

Multimodal Logistics Platforms (hereinafter referred to as MLPs) provide the best delivery times, reduce costs and increase the flexibility of uncertainty that may arise during a logistics flow. There are three MLP classifications: port logistics areas (maritime terminals), cargo terminals (specialized in air or land exchange) and container ports (terminals without access to inland waterways). $73 \%$ of MLPs operate on the basis of public-private partnership mechanisms. A government agency helps to resolve legal issues such as customs and tax laws. The private partner is responsible for managing the platform, overseeing its service providers, and accounting for platform maintenance and development [21]. The significant financial scope and technical complexity of the projects encourage investors to create broad PPP consortia and to select partners with extensive experience in PPP infrastructure projects. These strategies are expected to mitigate the risk and uncertainty associated with the complexity of PPP projects, as well as minimize the presence of weak institutional structures and political constraints. Higher technical complexity attracts private investors to joint cross-border PPP projects similar to those implemented in their home country.

The public authorities charged with evaluating the proposals of investors can determine the criteria for competitive selection in favor of large and experienced consortia of private enterprises, which involves the involvement of the most competitive participants of the partnership for their active participation in this process. It is legislatively expedient to introduce laws and regulations to simplify competitive selection procedures and attract the most relevant partners [3].

When PPP mechanisms are qualitatively shaped, this leads to positive results, namely: improving financial efficiency by attracting private capital, creating fiscal space to expand public service delivery in other sectors; improved governance by increasing the accountability of the service provider through competitive bidding, disclosure policies, and public reporting. The monopoly features of road infrastructure concessions make it possible, under effective public administration, to competitively select a strategic private investor, carry out regulatory oversight of contractual agreements, and disclose relevant information to the public [22].

Although transport is indispensable and beneficial to society, it is also the cause of several problems, the most important of which are con- gestion, pollution and road accidents. The use of technology reduces the impact of problems and at the same time provides new competitive solutions for businesses. So, these are the problems that intelligent transport systems solve - modern software designed to improve transport mobility, safety and productivity, optimize the use of gap infrastructures, increase energy efficiency, and increase the capacity of transport systems [23, p. 14]. Information and management is a key element in intelligent transport systems. All logistics partners (shippers, carriers and consignees) are interested in obtaining quality information (accurate, complete and timely) regarding transport operations. The private owner is looking for more efficient and reliable ways of delivering cargo, the public sector is focused on guaranteeing the safety and electronic control of vehicles. In the private sector, the most common software is truck and container tracking, in the public sector, control systems (electronic weighing, verification of credentials) are the leading systems [24, p. 196].

World experience demonstrates different approaches to using public-private partnerships to build logistics infrastructure. In the UK, PPP agreements use a payment mechanism based on safety factors, lane accessibility, congestion and minimum performance criteria. However, funding problems involve the use of real levies in future PPP road projects. Spain has a 15-year national plan covering the period 2005-2020 for various modes of transport, during which it is expected that approximately $25 \%$ of the required fund to operate national motorways will come from extrabudgetary concession sources. In Portugal, $15 \%$ of the current highways are operated under PPP contracts.

The ability to manage partnerships throughout the life of the contract is essential to delivering the expected services and maintaining public-private relations. The public sector's willingness to provide the enabling environment that will attract and support the private sector is crucial to the successful implementation of the program. In addition, the quality of management will benefit from the full benefits of private sector involvement and investment: due process of competitive selection of private owners, full disclosure of relevant projects to the public and the creation of a regulatory body to oversee contractual agreements throughout the concession period [25].

The implementation of PPP projects in the country depends on the presence of a high level: public and corporate governance; transparency and legal mechanisms, including ownership and contract law; control over corruption and related norms. Countries with higher participation of their citizens in the choice of representatives of 
different branches of government, freedom of speech have a higher level of investment in PPP. Government performance, regulatory quality and corruption control also affect investment, but to a lesser extent. Countries that have improved the quality of regulation and control over corruption over time tend to have higher levels of investment [26]. The transparency of the work of state authorities, the efficiency of administrative and legal mechanisms, the absence of bureaucratic obstacles and the minimization of corruption influences can significantly reduce the individual risks of PPP projects.

Logistics problems are solved by developing structured territorial logistics plans. Part of such plans is to involve all stakeholders in the operations and planning processes, as well as the entities involved in the policy and strategic planning processes [27, p. 87]. Openness of public authorities implies improvement of the system of placement of capital construction. Strategic planning of territorial development, investment flow management requires consideration of priority infrastructure projects, taking into account proposals from stakeholders, in particular integrated territorial communities. Public-private partnership is one of the essential mechanisms of development of territories, elements of increase of employment of the population, the driver of formation of the modern system of logistical infrastructure of the country. A balanced approach to attracting investors is impossible without forming the necessary legislative framework, modern territorial marketing and effective public administration in the sphere of public-private partnership.

Conclusions from the study and prospects for further exploration in this direction. Therefore, the study identified a significant impact of infrastructure on the growth of the economy and its competitiveness. Current financial needs do not provide the necessary level of logistics infrastructure development. Involvement of the private owner in the construction and operation of transport networks and their elements (ports, stations, terminals, etc.) will allow to meet the high requirements for infrastructure facilities and needs for investment resources. World practice shows examples of widespread use of public-private partnership mechanisms in the development of logistics strategies. Important criteria for implementing PPP projects are: reducing budget costs, minimizing project cost and time, sharing of risks between partners, improving quality of service, duration of partnerships, transparency of information and proper selection procedures, required level of institutional environment, minimizing corruption project implementation.

The opportunities of public-private partnership in the development of logistics infrastructure in Ukraine will give the necessary impetus to the economy as a whole, given the attraction of foreign investments, creation of modern infrastructure, which will increase the level of criteria of logistics efficiency and enhance the competitive advantages of our country as a transport hub between Europe and Asia.

\section{References:}

1. Proekt Natsionalnoi transportnoi stratehii Ukrainy na period do $2030 \mathrm{r}$. // Ministerstvo infrastruktury Ukrainy: ofitsiinyi sait. URL: https://mtu.gov.ua/projects/115/ (data zvernennia - 09.12.2019).

2. Pro skhvalennia Kontseptsii Derzhavnoi tsilovoi ekonomichnoi prohramy rozvytku avtomobilnykh dorih zahalnoho korystuvannia derzhavnoho znachennia na 2018-2022 rr.: rozporiadzhennia KMU vid 11 sichnia 2018 r. № 34-r / Verkhovna Rada Ukrainy. URL: http://zakon5.rada.gov.ua/laws/ show/34-2018-\%D1\%80 (data zvernennia - 09.12.2019).

3. Anempirical investigation of logistics infrastructure projects in emerging economies/ F. Parola, J.S.L. Lam. Maritime Economics \& Logistics. 2018. № 20 (1). P. 48-71.

4. Hryhorak M. Kontseptualni zasady rozvytku lohistychnoi infrastruktury v umovakh ekonomiky znan. Zbirnyk naukovykh prats Derzhavnoho ekonomiko-tekhnolohichnoho universytetu transportu. Seriia "Ekonomika i upravlinnia". 2013. Vyp. 26. S. 212-222.

5. Zhovtiak H. Teoretyko-metodychni pidkhody do vyznachennia poniattia "transportna infrastruktura rehionu". Efektyvna ekonomika. 2011. № 11. URL: http://nbuv.gov.ua/UJRN/ efek_2011_11_35 (data zvernennia 09.12.2019).

6. Is it time for an infrastructure push? The macroeconomic effects of public investment. World Economic Outlook. October 2014: Legacies, Clouds, Uncertainties. Washington, 2014. P. 75-114.

7. Pidbyvaiemo pidsumky roku: yak investory otsinyly biznes-klimat Ukrainy u 2-mu pivrichchi 2017 r. // Sait Yevropeiskoi biznes-asotsiatsii. URL: https://eba.com.ua/wp-content/ uploads/2017/12/ Release_IAI_2_half_2017_UKR.pdf (data zvernennia - 09.12.2019)

8. Transport // Dérzhānna șluzhba statystyky Ukrainy: ofitsiinyi sait. URL: http://www.ukrstat.gov.ua/ operativ /operativ2005/tz/tz rik/tz_u/ts_u.htm (data zvernennia - 12.12.2019).

9. Arvis J.F. et al. Trade logistics in the global economy: the logistics performance index and its indicators. Washington, 2016. 62 p.

10. Fabbro S. Mega Transport Infrastructure Planning. Springer, 2015. 264 p. 
11. Complexity and uncertainty: problem or asset in decision making of mega infrastructure projects? / W. Salet, L. Bertolini, M. Giezen. International Journal of Urban and Regional Research. 2013. № 37 (6). P. 1984-2000.

12. Zhang Y. From state to market: private participation in China's urban infrastructure sectors, 1992-2008. World Dev. 2014. № 64. P. 473-486.

13. Public-Private Partnerships. Reference Guide. Washington, D.C., 2012. 230 p.

14. Kumar M. Law, Statistics, Public-Private Partnership and the Emergence of a New Subject. Accumulation in Post-Colonial Capitalism. Singapore: Springer, 2017. P. 59-74.

15. Woetzel J. et al. Bridging global infrastructure gaps. New York: McKinsey and Company, 2016.9 p.

16. Private Participation in Infrastructure (PPI). Database 2017. Washington, 2017.

17. Private Financing of Public Infrastructure through PPPs in Latin America and the Caribbean / C. Garcia-Kilroy, H.P. Rudolph. Washington: World Bank, 2017. 14 p.

18. Chou J.S. et al. Critical factors and risk allocation for PPP policy: Comparison between HSR and general infrastructure projects. Transport Policy. 2012. № 22. P. 36-48.

19. Criteria for the management partnership model in Croatian seaports / A. Perić Hadžić, A. Jugović, M. Perić. Economic Research - Ekonomska Istraživanja. - 2015. - № 28(1). - P. 226-242.

20. Farrell S. The ownership and management structure of container terminal concessions. Maritime Policy \& Management: The flagship journal of international shipping and port research. 2012. № 39 (1). P. 7-26.

21. Mamede B.M. Multimodal logistic platforms structure analysis worldwide: a comparative study between Brazilian and foreign projects. Brazilian Journal of Operations \& Production Management. 2017. № 14 (3). P. 288-295.

22. Public-private partnerships in roads and government support: trends in transition and developing economies / C. Queiroz, N. Vajdic, G. Mladenovic. Transportation Planning and Technology. 2013. № 36 (3). P. 231-243.

23. Ortiz M.C. Los Sistemas Inteligentes de Transporte. Su aplicación a los modosterrestre, marítimo y aéreo. Madrid: Secretaría General de Transporte. Ministerio de Fomento, 2010. 72 p.

24. Javato-Martín M. et al. A Study of the Innovative Applications of Intelligent Transport Systems Works to Logistics and Freight Transport: Public-Private Collaboration Projects. Advances in Management Engineering. 2017. P. 195-205.

25. Road Transport Infrastructure Management in Selected Countries: an Appraisal / A. Adetola, J. Goulding, C.L. Liyanage. International Conference on Public Private Partnerships Body of Knowledge, 18-20 March 2013, University of Central Lancashire. 2013. P. 399-413.

26. Pérez-D'Oleo J. et al. The influence of the institutional environment on public-private partnership transport projects. WIT Transactions on The Built Environment. 2015. № 146. P. 399-410.

27. Private public collaboration on logistics in Norwegian cities / O. Eidhammer, J. Andersen, B. G. Johansen. Transportation Research Procedia. 2016. № 16. P. 81-88. 